\title{
Effect of administration of antibody against GnRH on preovulatory LH and FSH surges in the ewe
}

\author{
K. Narayana and Hilary Dobson \\ Department of Veterinary Clinical Studies, University of Liverpool, Leahurst, Neston, \\ Merseyside L64 7TE, U.K.
}

Summary. An antibody, raised in ewes against synthetic GnRH, was injected intravenously (a) before the expected synchronous surges of LH and FSH or (b) before the second FSH surge, i.e. at 0 or $20 \mathrm{~h}$ after the onset of behavioural oestrus. Control ewes were given normal sheep plasma at the same times.

One of the 4 ewes given antibody at $0 \mathrm{~h}$ showed blockade of the $\mathrm{LH}$ surge, whereas in the other 3 ewes there was an average delay of $16 \mathrm{~h}$ in the appearance of the LH peak and in 1 of the 3 there was a surge of FSH coincident with the delayed LH surge; no other surges of FSH were detected in any of the ewes between 0 and 48 $\mathrm{h}$ after the onset of oestrus. Endoscopic examination at 48-52 h showed follicles of 6-8 mm diameter with a papilla in all the 4 ewes but 2 ewes showed an abnormal luteal phase ( 32 and 34 days), indicated by plasma progesterone values.

The magnitude and the time of appearance of the second FSH surge was unaffected in all the 4 ewes treated with antibody $20 \mathrm{~h}$ after the onset of oestrus: 2 of the ewes had 6-8 $\mathrm{mm}$ follicles at the time of endoscopy, while the other 2 ewes and the controls had fresh corpora lutea haemorrhagica. Apart from 1 ewe with a long luteal phase all the other 5 treated and control ewes had a fertile oestrus $19 \cdot 0 \pm 0.4$ days after the experiment.

Administration of antibody $2 \mathrm{~h}$ after a $4-\mathrm{h}$ infusion of oestradiol $(3 \mu \mathrm{g} / \mathrm{h})$ to 3 anoestrous ewes completely blocked the LH surge in one and produced a 6 and $3 \mathrm{~h}$ delay of an LH surge of decreased magnitude in the other 2 ewes. The FSH surge was blocked in 2 ewes and in the other was asynchronous with the LH surge.

The results suggest that GnRH controls the preovulatory synchronous $\mathrm{LH}$ and FSH surges, but not the second FSH surge.

\section{Introduction}

The evidence that gonadotrophin-releasing hormone ( $\mathrm{GnRH})$ is the sole releasing hormone for both luteinizing hormone ( $\mathrm{LH})$ and follicle-stimulating hormone (FSH) is based on the fact that pharmacological doses of GnRH cause the release of LH and FSH (Schally et al., 1976). Also, administration of GnRH antibody has been shown to block $\mathrm{LH}$ and FSH surges in the rat (Arimura, Debeljuk \& Schally, 1974; Kerdelhue, Catin, Kordon \& Jutisz, 1976) and the hamster (De La Cruz, Arimura, De La Cruz \& Schally, 1976). There is a report (Kerdelhue, Jutisz, Gillesen \& Studer, 1973) of a rise in jugular plasma GnRH concentration synchronous with LH and FSH surges in the ewe. Later studies, however, have indicated no relationship between LH and GnRH in the ovine jugular plasma (Nett, Akbar \& Niswender, 1974; Jonas, Burger, Cumming, Findlay \& de Krester, 1975; Foster, Jeffcoate, Crighton \& Holland, 1976), and it is considered that the concentration of $\mathrm{GnRH}$ in the peripheral blood is probably below the limit of assays currently available(Nett \& Adams, 1977). -

* Present address: Veterinary College, Hebbal, Bangalore 560024, India. 
The present experiment was designed to investigate the role played by $\mathrm{GnRH}$ in the control of the synchronous LH and FSH surges and the second FSH surge after the onset of oestrus in the ewe. The response to passive immunization against GnRH was measured in terms of jugular plasma $\mathrm{LH}$ and FSH concentrations.

\section{Materials and Methods}

\section{Raising antibodies against synthetic GnRH}

Two ewes were immunized against synthetic GnRH (Abbott, Lot 41070) by the method of Fraser, Gunn, Jeffcoate \& Holland (1974) with slight modifications. Using $125 \mathrm{mg}$ carbodiimide (Sigma), $5 \mathrm{mg} \mathrm{GnRH}$ were conjugated to $5 \mathrm{mg}$ bovine serum albumin (Armour Pharm.). After dialysis, the conjugate in saline plus $1 \mathrm{ml}$ Pertussis vaccine (Lilly Laboratories, U.S.A.) was emulsified in Freund's complete adjuvant (Difco, U.S.A.) for the primary immunization. In the later immunizations, Freund's incomplete adjuvant was used. Each ewe was given $2 \mathrm{ml}(1 \mathrm{mg}$ GnRH-BSA) subcutaneously. After secondary immunizations pooled plasma giving about $50 \%$ specific binding at a dilution of $1: 2000$ in a double-antibody radioimmunoassay was used in the following studies.

Normal sheep plasma (NSP) was collected from ewes on Day 3 of the oestrous cycle and had concentrations of $<0.2 \mathrm{ng}$ progesterone $/ \mathrm{ml}$ and $4.5 \mathrm{pg}$ oestradiol $/ \mathrm{ml}$.

\section{Animals}

Mature parous Clun Forest ewes were housed indoors with a vasectomized raddled ram. Experiments were carried out in February, January and August. One day before the beginning of each experiment polythene catheters (p.p. 120: Portex) were introduced into a jugular vein under local anaesthesia (Xylocaine: Astra).

\section{Synchronization of oestrus}

An analogue of prostaglandin F-2 $\alpha$, cloprostenol (Estrumate: I.C.I. ), was injected intramuscularly in 2 doses, $125 \mu \mathrm{g}$ each, 9-10 days apart. About 40-48 h after the second cloprostenol injection, when the onset of oestrus was indicated by the ram, each ewe was moved into an individual pen.

\section{Experimental design}

Group 1. Two ewes were injected with $30 \mathrm{ml} \mathrm{NSP} \mathrm{i.v.} \mathrm{at} \mathrm{the} \mathrm{onset} \mathrm{of} \mathrm{oestrus}(0 \mathrm{~h})$.

Group 2. Two ewes were injected i.v. with $30 \mathrm{ml} \mathrm{NSP} 20 \mathrm{~h}$ after the onset of oestrus.

Group 3. Four ewes were injected i.v. with $30 \mathrm{ml} \mathrm{GnRH}$ antibody at $0 \mathrm{~h}$.

Group 4. Four ewes were injected i.v. with $30 \mathrm{ml} \mathrm{GnRH}$ antibody at $20 \mathrm{~h}$.

The ovaries of all these ewes were examined with the aid of a fibre-optic endoscope (Wolf 7134: Knittlingen, West Germany) for evidence of ovulation 48-52 h after the onset of oestrus.

Groups 5 and 6. On Day 3 of the cycle, ewes were injected with $30 \mathrm{ml}$ NSP i.v. (2 ewes, Group 5) or $30 \mathrm{ml} \mathrm{GnRH}$ antibody i.v. (3 ewes, Group 6) and 30 min later with $50 \mu \mathrm{g} \mathrm{GnRH}$ i.v. (a gift from Dr H. Gregory, I.C.I.).

Groups 7 and 8. On Day 3 of the cycle, ewes were injected with $30 \mathrm{ml}$ NSP i.v. ( 3 ewes, Group 7) or $30 \mathrm{ml} \mathrm{GnRH}$ antibody i.v. (3 ewes, Group 8) and $10 \mathrm{~min}$ later with $20 \mu \mathrm{g} \mathrm{GnRH}$ i.v.

Groups 9 and 10. Ewes were infused at $0 \mathrm{~h}$ with $3 \mu \mathrm{g}$ oestradiol-17ß (Koch-Light, U.K.)/h for $4 \mathrm{~h}$ and at $6 \mathrm{~h} 30 \mathrm{ml}$ NSP ( 3 ewes, Group 9) or $30 \mathrm{ml} \mathrm{GnRH}$ antibody (3 ewes, Group 10) were injected through the jugular catheter. 


\section{Blood sampling}

Heparinized blood samples ( $5 \mathrm{ml}, 50 \mathrm{i} . \mathrm{u}$. heparin $/ \mathrm{ml}$ ) were collected through the indwelling catheter at $2 \mathrm{~h}$ intervals for $24 \mathrm{~h}$ in anoestrous ewes and for $48-52 \mathrm{~h}$ in oestrous ewes. Every $6 \mathrm{~h}$, $30 \mathrm{ml}$ blood were collected for oestradiol assay. Blood samples $(5 \mathrm{ml})$ were collected from the ewes in Groups 5-8 every $15 \mathrm{~min}$ for $5 \mathrm{~h}$. The blood samples were immediately centrifuged at $700 \mathrm{~g}$ for $15 \mathrm{~min}$ and the plasma was stored at $-15^{\circ} \mathrm{C}$ until analysis.

Blood samples $(5 \mathrm{ml})$ were also collected from the ewes in Groups $1-4$ by jugular venepuncture every 2 or 3 days for 50 days for progesterone assay.

\section{Radioimmunoassay of hormones}

The concentrations of LH, FSH, oestradiol-17 $\beta$ and progesterone were measured by methods already described (Niswender, Reichert, Midgley \& Nalbandov, 1969; Dobson \& Ward, 1977; Pant, Hopkinson \& Fitzpatrick 1977). Assaying a plasma sample of low hormone concentration, the respective inter- and intra-assay coefficients of variation were $17.8(n=15)$ and $13.0 \%(n=6)$ for LH, $14 \cdot 0(n=12)$ and $5 \cdot 8 \%(n=8)$ for FSH, $13 \cdot 3(n=6)$ and $16 \cdot 3 \%$ $(n=8)$ for oestradiol, and $17 \cdot 1(n=10)$ and $10.4 \%(n=10)$ for progesterone. Assaying a plasma sample of high hormone concentration the respective inter- and intra-assay coefficients of variation were $9.1(n=12)$ and $9.0 \%(n=10)$ for LH, $16.6(n=12)$ and $14.4 \%(n=6)$ for FSH, $6.4(n=8)$ and $9.4 \%(n=10)$ for oestradiol, and $18.2(n=10)$ and $23 \cdot 1 \%(n=10)$ for progesterone. The results are expressed as $\mathrm{ng}$ equivalents $/ \mathrm{ml}$ of $\mathrm{NIH}-\mathrm{LH}-\mathrm{S} 16 / \mathrm{ml}$ for the LH assay and as NIH-FSH-S10/ml for the FSH assay. The sensitivity of the method for LH was 0.2 $\mathrm{ng} /$ tube and for FSH $5 \mathrm{ng} / \mathrm{tube}$. The water blank values for the oestradiol and progesterone assays were $1.1 \pm 0.3$ (s.e.m.) $(n=36)$ and $16.3 \pm 3.9(n=20) \mathrm{pg} / \mathrm{ml}$ respectively; the plasma steroid values were thus not corrected for 'method blank'. Recovery of radioactive oestradiol from plasma was $85 \cdot 3 \pm 3 \cdot 1 \%(n=18)$ and of progesterone $74.5 \pm 4.6 \%(n=10)$. Addition of $1: 1000 \mathrm{GnRH}$ antibody had no effect on the standard curve of either gonadotrophin.

The binding of GnRH antibody in the pooled plasma was determined according to the method of Jeffcoate, Fraser, Holland \& Gunn (1974) with slight modifications. ${ }^{125}$ I-labelled GnRH (50 000 c.p.m.) was added to serial dilutions of antibody and the separation of bound hormone was carried out using a second antibody against sheep- $\gamma$-globulin raised in our laboratory. Cross-reaction studies kindly performed by Dr H. M. Fraser (M.R.C. Unit of Reproductive Biology, Edinburgh) revealed high cross-reactions with the 2-10, 3-10 and 4-10 fragments of GnRH.

In the recipient ewes, the total binding capacity of the plasma was also determined. Plasma samples $(200 \mu \mathrm{l})$ and ${ }^{125} \mathrm{I}$-labelled GnRN $(200 \mu \mathrm{l})$ were incubated at $4^{\circ} \mathrm{C}$ for $48 \mathrm{~h}$ and then the unbound hormone was removed with $0.5 \mathrm{ml}$ cold $0.25 \%$ charcoal in $0.1 \%$ gelatin- $0.15 \mathrm{M}$-PBS. After centrifugation at $3000 \mathrm{~g}$ for $10 \mathrm{~min}$ the supernatant was counted and the total binding capacity was considered as the c.p.m. in the supernatant expressed as a percentage of c.p.m. added initially.

\section{Statistical analyses}

All the values are expressed as mean \pm s.e.m. and Student's $t$ test was used to compare the treated with both control groups.

\section{Oestrous ewes}

\section{Results}

In both control groups (Groups 1 and 2), the patterns of plasma gonadotrophin concentrations were similar and for the purpose of statistical analysis they were combined. Considering maximum LH concentration as $0 \mathrm{~h}$, composite graphs calculated for control and treated ewes are shown in Text-fig. 1 (one ewe in Group 3 which showed complete blockade of the LH surge was not considered in this composite graph). Relative to the onset of behavioural oestrus, 


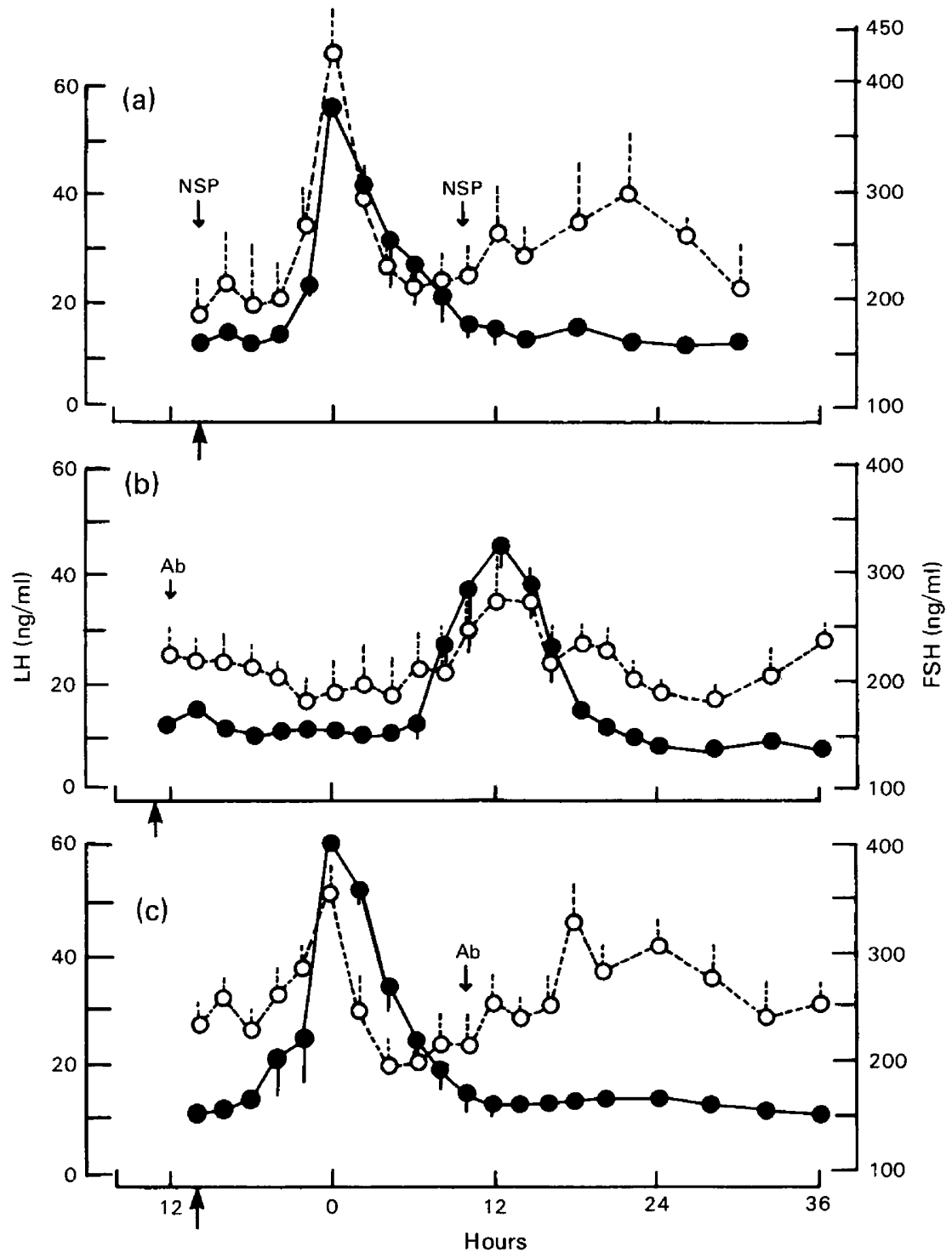

Text-fig. 1. Mean \pm s.e.m. jugular plasma concentrations of LH $(O)$ and FSH $(O)$ in ewes treated with (a) normal sheep plasma (NSP), $30 \mathrm{ml}$ i.v. (Groups 1 and 2, 5 ewes), or an antibody (Ab) against synthetic GnRH at (b) $0 \mathrm{~h}, 3$ ewes, or (c) $20 \mathrm{~h}, 4$ ewes, after the onset of oestrus (arrows). One ewe (Ewe 20), which showed complete blockade of the gonadotrophin surge, is not included in (b).

maximum $\mathrm{LH}$ concentrations were noted at $10.3 \pm 1.3 \mathrm{~h}$ in the controls (Groups $1+2$ combined) and at $26.7 \pm 4.4 \mathrm{~h}$ in Group $3(P<0.001)$. The maximum LH concentration in Group $3(45.0 \pm 5.0 \mathrm{ng} / \mathrm{ml})$ was not significantly different from that of the combined control group $(52 \cdot 5 \pm 2 \cdot 5 \mathrm{ng} / \mathrm{ml})$.

Only one ewe in Group 3 showed an FSH surge synchronous with that of the delayed LH surge; there was no obvious first or second FSH surge in the other 3 ewes. It is the FSH concentration of this ewe which, upon calculation of the mean, appears to show an FSH surge synchronous with the LH surge in the composite graph (Text-fig. 1b). The second maximum 
FSH concentration in Groups $1+2$ was $298.8 \pm 46.4 \mathrm{ng} / \mathrm{ml}$ and in Group 4 was $327.5 \pm 33.0$ $\mathrm{ng} / \mathrm{ml}$ at a mean time of $34.5 \mathrm{~h}$ after the onset of oestrus (in both groups).

The binding capacity of the antibody in the recipient ewes declined rapidly within 1 week. Afterwards, there was slow decline which persisted for at least 21 days. The mean \pm s.e.m. binding capacity for ${ }^{125} \mathrm{I}$-labelled $\mathrm{GnRH}$ at Days $0,1,7,14$ and 21 was $45 \cdot 8 \pm 0 \cdot 7,99 \cdot 2 \pm 0 \cdot 2$, $80.9 \pm 0.8,73.4 \pm 1.5$ and $67.8 \pm 1.3 \%$ respectively.

In Groups $1+2,2$ ewes had a jugular plasma oestradiol concentration of $10.2 \mathrm{pg} / \mathrm{ml} 2 \mathrm{~h}$ before the onset of oestrus. In the other 2 ewes, maximum plasma oestradiol concentrations at the onset of oestrus were 6.1 and $4.3 \mathrm{pg} / \mathrm{ml}$. In Group 3, the maximum oestradiol concentration in individual ewes was $9.7,10.2,9.7$ and $4.8 \mathrm{pg} / \mathrm{ml}$ at $0,12,0$ and $0 \mathrm{~h}$ from the onset of oestrus respectively. In blood samples collected between 18 and $30 \mathrm{~h}$ after the onset of oestrus, the mean oestradiol concentrations were $6.4 \pm 0.6 \mathrm{pg} / \mathrm{ml}$ in Group 2 and $5.7 \pm 0.6 \mathrm{pg} / \mathrm{ml}$ in Group 4 . There was no significant rise in plasma oestradiol concentration in control or treated ewes before the second FSH surge.

The ovaries of all the ewes in Group 3 and those of 2 ewes in Group 4 had 1 or 2 ripe follicles with a papilla 6-8 mm diameter at the time of endoscopy (48-52 h after the onset of oestrus). The other 2 treated ewes in Group 4 and all the control ewes showed 1 or 2 fresh corpora lutea haemorrhagica. At 6 days after the start of the experiment plasma progesterone concentrations in Groups $1+2$, Group 3 (except Ewe 20) and Group 4 were $1 \cdot 1 \pm 0 \cdot 1,1 \cdot 3 \pm$ 0.5 and $1.5 \pm 0.6 \mathrm{ng} / \mathrm{ml}$ respectively. There was then sustained rise to $\geqslant 1.5 \mathrm{ng} / \mathrm{ml}$ until values declined before oestrus to reach $0.2 \mathrm{ng} / \mathrm{ml}$. In Ewe 20 in Group 3, which showed complete blockade of the LH surge, the progesterone concentrations were $0.2,0.4,0.3,0.6$ and 1.2 $\mathrm{ng} / \mathrm{ml}$ on Days $0,6,8,10$ and 13 respectively, and remained at this level until they declined to $0.4 \mathrm{ng} / \mathrm{ml}$ on Day 34, when behavioural oestrus occurred. Another ewe, which showed partial LH blockade, showed behavioural oestrus after 32 days. One ewe in Group 4 had a luteal phase of 45 days and went into anoestrus during mid-March. All the other ewes in the 4 groups became oestrous $19.4 \pm 0.4$ days after the experiment, and all conceived and subsequently gave birth to 1 or 2 lambs.

\section{Day 3 of the oestrous cycle}

In ewes treated with GnRH antibody the maximum LH concentrations noted 45 min after $50 \mu \mathrm{g} \mathrm{GnRH}$ was $31.7 \pm 1.7 \mathrm{ng} / \mathrm{ml}$ (Group 6) compared with the values of $45.0 \pm 5.0 \mathrm{ng} / \mathrm{ml}$ in the control ewes (Group 5). In Group 8 maximum LH concentration reached $1 \mathrm{~h}$ after $20 \mu \mathrm{g}$ GnRH was $21.0 \pm 4.0 \mathrm{ng} / \mathrm{ml}$ compared with the value of $42.5 \pm 2.5 \mathrm{ng} / \mathrm{ml}$ in the control ewes (Group 7). There was no definite pattern of FSH release in the antibody-treated ewes. Maximum FSH concentration was reached at 2 and $1.5 \mathrm{~h}$ in Groups 5 and 7 and was 400 \pm 100 and $260 \pm 70 \mathrm{ng} / \mathrm{ml}$ respectively. In Groups 6 and $8 \mathrm{FSH}$ concentrations at these times were $150.0 \pm 37.9$ and $151.3 \pm 12.9 \mathrm{ng} / \mathrm{ml}$ respectively.

\section{Anoestrous ewes infused with oestradiol}

In the control ewes $12-14 \mathrm{~h}$ from the start of oestradiol infusion, there were synchronous $\mathrm{LH}$ and FSH surges (Text-fig. 2a); the maximum concentration of $\mathrm{LH}$ was $55 \cdot 3 \pm 3.3 \mathrm{ng} / \mathrm{ml}$ and of FSH $350.0 \pm 80.4 \mathrm{ng} / \mathrm{ml}$. One of the ewes treated with $\mathrm{GnRH}$ antibody showed complete blockade of oestradiol-induced LH and FSH surges (F6 in Text-fig. 2b). In the same ewe, the baseline $\mathrm{LH}$ concentration was also reduced by $50 \%$ from the pretreatment value of $3.75 \pm 0.3$ $\mathrm{ng} / \mathrm{ml}(n=4)$ to a post-treatment value of $1.75 \pm 0.25 \mathrm{ng} / \mathrm{ml}(n=9)$. In the other two treated ewes there was a delay of 6 and $3 \mathrm{~h}$ respectively in the appearance of the LH surge which was itself of decreased magnitude, 35 and $40 \mathrm{ng} / \mathrm{ml}$. One of the treated ewes showed an FSH surge which was asynchronous with the LH surge. 
(Iw/6u) HS
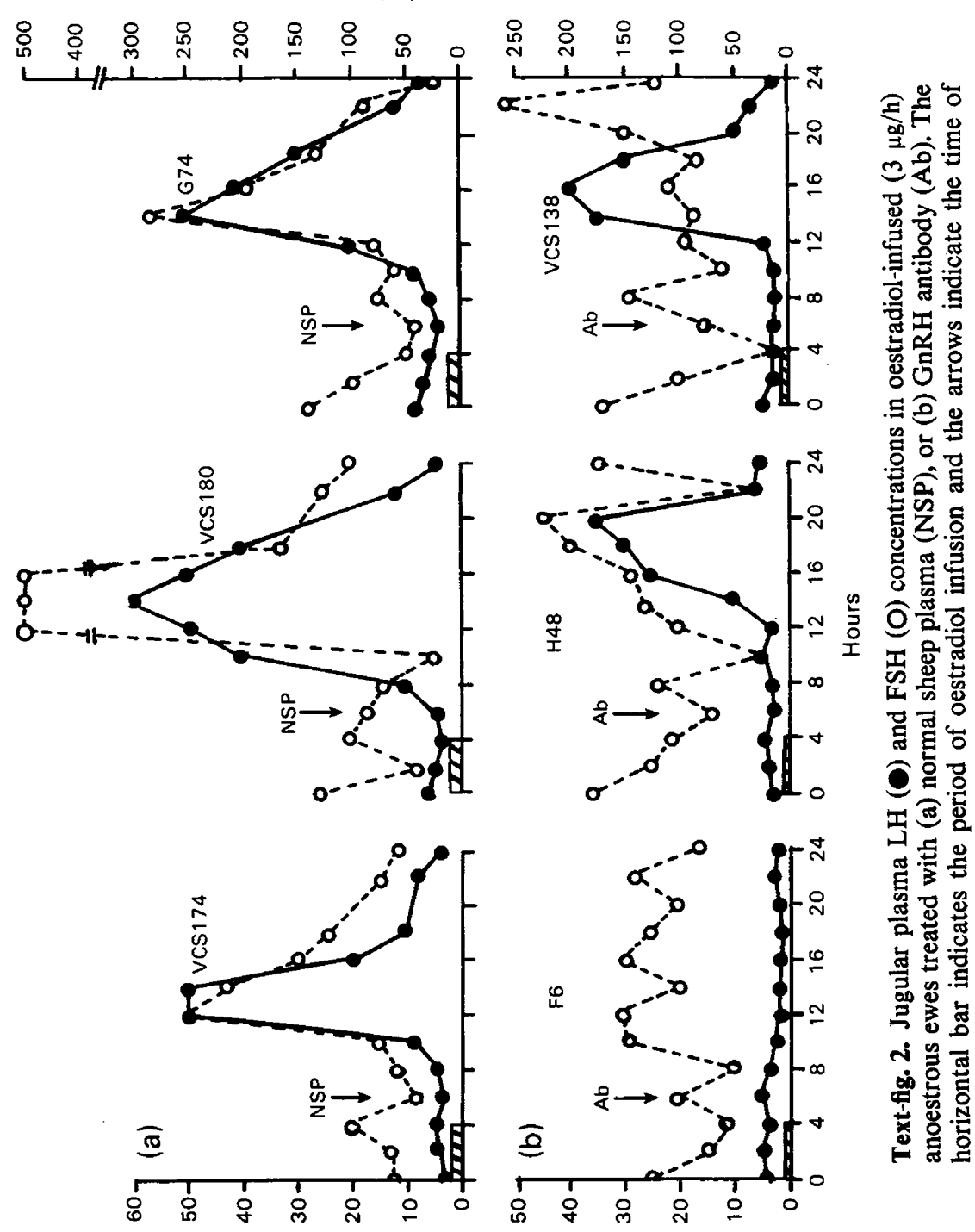

is

영형

营客。

楚

8 ㅌ․․

음음

栨设

红兵䓵

预苍

응음

䏯志

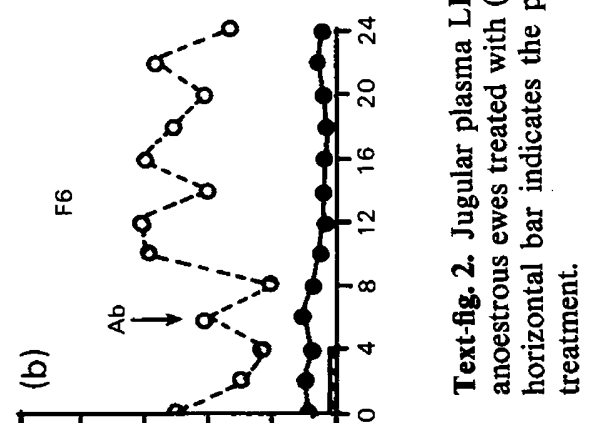

(Iw/6u) $\mathrm{HT}$ 


\section{Discussion}

In the present study, administration of GnRH antibody before the expected synchronous surge of gonadotrophins at oestrus or after oestradiol infusion to anoestrous ewes produced a decline or a delay of the LH and FSH surges and blocked ovulation. This suggests that neutralization of endogenous GnRH affects normal gonadotrophin release in sheep in accordance with the reports of such inhibition in the rat (Arimura et al., 1974; Kerdelhue et al., 1976), hamster (De La Cruz et al., 1976) and rhesus monkey (McCormack, Plant, Hess \& Knobil, 1977). It is probable that the antibody was neutralizing circulating $\mathrm{GnRH}$, as there is no evidence to show that antibodies penetrate nerve endings where the neurohormone is stored. When the antibody falls below a critical concentration, the released free GnRH would be able to exert an effect on pituitary gonadotrophs in order to induce gonadotrophin surges. In ewes which showed complete blockade of gonadotrophin surge (noted during the sampling period), it is likely that the antibody concentration was sufficient to neutralize the continued release of GnRH.

The evidence that our antibody was directed against $\mathrm{GnRH}$ comes from the study of the effect of exogenously administered GnRH on gonadotrophin release in antibody-treated ewes. Lack of complete blockade of the GnRH-induced gonadotrophin release in the antibody-treated ewes could have been due to the large dose of $\mathrm{GnRH}$ employed $(20 \mu \mathrm{g})$. As GnRH induces immediate $\mathrm{LH}$ release, the time required to attain antigen-antibody equilibrium was probably too great to allow complete block of LH release. Before maximum FSH release was reached greater equilibrium may have been attained, thus enabling the antibody to inhibit the duration and magnitude of the FSH surge to a greater extent. In each experiment except Group 4, FSH release was more sensitive than LH to blockade by $\mathrm{GnRH}$ antibody.

Pant et al. (1977) found maximum oestradiol concentrations in the jugular blood before the onset of behavioural oestrus. In the present study, there was not a high oestradiol concentration preceding gonadotrophin surge in all the ewes because blood sampling was started at the onset of oestrus. However, the apparent lack of rise in oestradiol concentration preceding the second FSH surge in the control oestrous ewes and the ability of exogenous oestradiol to induce synchronous gonadotrophin surges followed by a second isolated FSH surge in the anoestrous ewe (Dobson \& Ward, 1977; Pant, 1977) strongly suggest that the oestradiol stimulus brings about short- and long-term changes in neuronal activity leading to FSH release. That this may be brought about via $\mathrm{GnRH}$ is deduced from the alteration of the total pattern of FSH release in the ewes in Group 3. With this hypothesis however it is difficult to account for the second surge of FSH alone and to explain the fact that there was marked inhibition of first FSH surge and GnRH-induced FSH release but not of the second FSH surge after GnRH antibody. Although there is a report of the purification of FSH-releasing hormone (Johansson et al., 1975) there has been no confirmation of its isolation or synthesis.

In spite of ovulation blockade in ewes treated with $\mathrm{GnRH}$ antibody at the onset of oestrus, as reflected by the plasma progesterone profile, ovulation could have occurred after the endoscopic examination (48-52 h after the onset of oestrus) or anovulatory luteinization of follicle(s) could have taken place. Surprisingly, in 2 of 4 ewes given antibody $20 \mathrm{~h}$ after the onset of oestrus (about $13.5 \mathrm{~h}$ after the preovulatory $\mathrm{LH}$ and FSH surge) there was no fresh corpus luteum haemorrhagicum.

K.N. is grateful to The Commonwealth Scholarship Commission U.K., and H.D. to the Lalor Foundation for financial support. We thank Professor W. Hansel for LH antibody; Professor L. E. Reichert, Jr and NIAMDD for purified oFSH, oLH, GnRH and anti-rat FSH; Dr D. B. Harker, I.C.I., for Estrumate; Dr W. R. Ward for help with bleeding and surgery; and Professor R. J. Fitzpatrick for encouragement and facilities. 


\section{References}

Arimura, A., Debeljuk, L. \& Schally, A.V. (1974) Blockade of preovulatory surge of $\mathrm{LH}$ and $\mathrm{FSH}$ and of ovulation by anti-LHRH serum in rats. Endocrinology 95, 323-325.

De La Cruz, A., Arimura, A., De La Cruz, K. \& Schally, A.V. (1976) Effect of administration of antiserum to LHRH on gonadal function during the estrous cycle in the hamster. Endocrinology 98, 490-497.

Dobson, H. \& Ward, W.R. (1977) Alterations in plasma gonadotrophin patterns caused by sodium pentobarbitone in ewes at oestrus and in anoestrous ewes after infusion of oestradiol. $J$. Endocr. 75, 109118.

Foster, J.P., Jeffcoate, S.L., Crighton, D.B. \& Holland, D.T. (1976) Luteinizing hormone and luteinizing hormone-releasing hormone-like immunoreactivity in the jugular venous blood of sheep at various stages of the oestrous cycle. J. Endocr. 68, 409-417.

Fraser, H.M., Gunn, A., Jeficoate, S.L. \& Holland, D.T. (1974) Preparation of antisera to LH-releasing hormone. J. Endocr. 61, ix-X.

Jeffcoate, S.L., Fraser, H.M., Holland, D.T. \& Gunn, A. (1974) Radioimmunoassay of luteinizing hormonereleasing hormone in serum from man, sheep and rat. Acta endocr., Copenh. 75, 625-635.

Johansson, K.N.G., Greibrokk, T., Currie, B.L., Hansen, J., Folkers, J. \& Bowers, C.Y. (1975) Factor CLHIH which inhibits the $\mathrm{LH}$ from basal release and from synthetic LHRH and studies on purification of FSHRH. Biochem. Biophys. Res. Commun. 63, 6268.

Jonas, H.A., Burger, H.G., Cumming, I.A., Findlay, J. K. \& de Krester, D.M. (1975) Radioimmunoassay for luteinizing hormone-releasing hormone: its application to the measurement in ovine and human plasma. Endocrinology 96, 384-393.

Kerdelhue, B., Jutisz, M., Gillesen, D. \& Studer, R.C. (1973) Obtention of antisera against a hypothalamic decapeptide ( $\mathrm{LH} / \mathrm{FSH}$ releasing hormone) which stimulates the release of pituitary gonadotrophins and development of its radioimmunoassay. Biochim. Biophys. Acta 297, 540-548.

Kerdelhue, B., Catin, S., Kordon, C. \& Jutisz, M. (1976) Delayed effects of in vivo LHRH immunoneutralisation on gonadotropins and prolactin secretion in the female rat. Endocrinology 98, 15391549.

McCormack, J.T., Plant, T.M., Hess, D.L. \& Knobil, E. (1977) The effect of LHRH antiserum administration on gonadotropin secretion in the rhesus monkey. Endocrinology 100, 663-667.

Nett, T.M. \& Adams, T.E. (1977) Further studies on the radioimmunoassay of gonadotropin-releasing hormone: effect of radioiodination, antiserum and unextracted serum on levels of immunoreactivity in serum. Endocrinology 101, 1135-1144.

Nett, T.M., Akbar, A.M. \& Niswender, G.D. (1974) Serum levels of luteinizing hormone and gonadotropin-releasing hormone in cyclic, castrated and anoestrous ewes. Endocrinology 94, 713-718.

Niswender, G.D., Reichert, L.E., Jr, Midgley, A.R., Jr, \& Nalbandov, A.V. (1969) Radioimmunoassay of bovine and ovine luteinizing hormone. Endocrinology 84, 1166-1173.

Pant, H.C. (1977) Effect of oestradiol infusion on plasma gonadotrophins and ovarian activity in progesterone-primed and unprimed anoestrous ewes. $J$. Endocr. 73, 227-233.

Pant, H.C., Hopkinson, C.R.N. \& Fitzpatrick, R.J. (1977) Concentration of oestradiol, progesterone, luteinizing hormone and follicle-stimulating hormone in the jugular venous plasma of ewes during the oestrous cycle. J. Endocr. 73, 247-255.

Schally, A.V., Arimura, A., Redding, T.W., Debeljuk, L., Carter, W., Dupont, A. \& Vilchez-Martinez, J.A. (1976) Re-examination of porcine and bovine hypothalamic fractions for additional LH and FSH releasing activities. Endocrinology 98, 380-391. 